\title{
Developing policy on integration and re/construction in Kosova ${ }^{1}$
}

\section{Chris Corrin}

The Gender Audit (GA) and associated reports and reviews drawn upon in this article enable an evaluation of how far the intervention processes at work in Kosova since 1999 have been inclusive of gender analysis and supportive of women's and girls' needs and interests. This assessment considers the strengths and drawbacks of various attempts to use and implement gender-sensitive projects. The GA was designed to support the emerging feminist reconstructive politics in Kosova. Its findings and recommendations tackle aspects of empowerment, equity, and opportunities, outlining some developments from community activism as well as outcomes of the international administration. By considering developments over a two-year period, it is possible to place issues of equity and opportunities in the context of change over time, with change at local and national levels linked with developing international dialogues. The article analyses local work undertaken by the Kosova Women's Network to overcome violence against women in war and domestic peace, and reviews international work engaged in by the Kosovo [sic] Women's Initiative (KWI). Many Kosovar women (of all ethnicities) do fully acknowledge their community membership, and recognise the risks involved in talking across their differences to achieve everyday security and reconciliation. International reports and reviews such as those produced in 2002 by the UN Secretary-General and UNIFEM on women, war, peace, and security, as well as the review of the KWI, allow an assessment of how dialogues are changing and what the potential impact of such change might be on policy development and implementation.

\section{Introduction}

While I have addressed post-conflict reconstruction and gender analysis in Kosova using the Gender Audit (GA) ${ }^{2}$ elsewhere (Corrin 2000, 2001), my focus in this article is on the impact that changes in dialogue have had on the policy toward and support for local women's work in reducing gender imbalances and gender-based violence in Kosova. A central area of concern in undertaking the GA was to assess the extent to which women's social, economic, educational, and political participation has been encouraged-both in 'informal' civic forums and organisations, and at the formal levels of power. For continuity and in the interests of follow-up projects, the GA assesses 'gaps' in policy making, service provision, data collection, and the coordination and monitoring of projects designed to increase the participation of women and girls. The GA suggests additional monitoring, investigation, and collaborative efforts to bring about the full integration of women and girls in the re/construction of societies in south-east Europe. In view of the fact that the critiques and some recommendations from the 
GA have been taken up in two recent UN reports (one by the Secretary-General and the other by UNIFEM), as well as in the Kosovo [sic] Women's Initiative (KWI) Review, the GA has already made some input to the analytical decision-making framework. ${ }^{3}$

The situation in which the UN Mission in Kosova (UNMIK) came to be the governmental power was one of tension and turmoil following the NATO bombing of Kosova and Serbia. Much has been written about this intervention and the gendered aspects of conflict and postconflict developments (see Hasani 2000; Judah 2000; Maliqi 1998; Mertus 1999; Waller et al. 2001). Peacekeeping has evolved to include areas of humanitarian relief, refugee return, demining, civilian policing, demobilisation, human rights monitoring, elections, and nation building. ${ }^{4}$ Contrasting, and sometimes competing, agendas and perspectives highlight ongoing tensions between international and local needs and interests, and between short-term crisis aid and long-term development planning. The various official international groups, including those involved in UNIFEM, KWI, and UNMIK (Gender Affairs), were working with these tensions to varying effect. Cross-collaboration seemed to be something that was difficult to implement or maintain but clearly had a highly significant impact. Through the work of feminist international NGOs, it has been possible to develop a somewhat more sustainable collaboration with local women's organisations (see Corrin 2000 for more detail on this and on how the work of UNIFEM succeeded in bridging some of the gaps between the bilateral collaboration with local and international NGOs and international organisations within UNMIK).

\section{Coping with violence and conflict}

For many millions of women throughout the world, the vital struggle they engage in every day is for freedom from external aggression. Kosovar Albanian women ${ }^{5}$ were centrally involved in resisting state oppression-both in the parallel social and economic systems that began in 1989 and in non-violent resistance. During the armed resistance, women fought in the Kosova Liberation Army (KLA) and actively supported the struggle. ${ }^{6}$ The legacies of such involvement remain in women's realities today. ${ }^{7}$ Because democratic politics cannot develop under oppression by external powers, gaining freedom from Serb rule was a basic necessity in order to develop a political, social, and economic system that was democratic and participatory. Ideas regarding peaceful resistance were the subject of much discussion throughout Kosova in the ten years preceding 1999, as most people desperately wanted the non-violent resistance led by Ibrahim Rugova to succeed (for more details on this movement, see Waller et al., 2001). War was viewed as the failure of this resistance.

The ways in which the struggle was carried out determined something of the outcome regarding gender relations, but the lack of a national government presents an unusual environment for developing a democratic system. Women are involved in the new and expanding police forces, in de-mining projects, in running farms, and in businesses. There is growing recognition of the need to deconstruct certain attitudes towards violence, and to include women's cultural experiences alongside those of men. And because the Kosovar population is predominantly young, with around half being under 25 years of age, there is great potential to revolutionise gender relations, especially with experience from the diaspora.

Peace is not just the absence of war, and the violence experienced in war remains part of a continuum of gender-based violence that threatens many women in their daily lives (Corrin 1996; Davies 1994; Jacobs et al. 2001; Meintjes et al. 2001). Distinctions between war and post-war often remain unclear. In Kosova, the difference was brought about by a very fragile 'peace' negotiated at Rambouillet. This negotiated cessation of violence privileged the 'men at war' while it excluded women and other civil society representatives. But it is vital for civic groups, especially feminist organisations, to be involved in discussions and policy making 
regarding the peaceful reconstruction of their societies, especially given their expertise and their political will to talk across differences towards agreement. That Milosevic would not accept peacekeepers did not make the bombing necessary. Having threatened such military action, however, it was believed that NATO authorities would have lost credibility if they had failed to carry through. While (formal) armed conflict could be said to have ceased after the end of the bombing campaign, Kosova was by then awash with weapons and military personnel, and revenge attacks continued. Inter-ethnic and political violence was the UNMIK's main focus, yet police crime statistics reported violence against women as equally common (see www.civpol.org.unmik). Heightened levels of public violent crime are not uncommon in post-war situations.

In such circumstances, survivors are traumatised and, most importantly for the purposes of this paper, the trauma is gendered. Cynthia Cockburn (2001:25) points out that many men who were wounded in conflict are doomed to unemployment, and that women and children in rural areas are highly exposed to landmine accidents. In the case of Kosova, women were additionally traumatised by war rapes and by the loss of their menfolk. ${ }^{8}$ Many Kosovar Albanian women and men were also betrayed by lifelong Serb neighbours (for instance, several families remained concealed in cellars without food and light for days before their neighbours directed Serb military and paramilitary soldiers to their hiding places). It is because of such specificities of war that the 'hard talking' of peace needs to include women's voices. Hannan Ashrawi, a former participant in Israeli-Palestinian peace talks, has stated that women bring to the table the need to talk directly about the most difficult issues rather than postponing them or getting entangled in bureaucratic logic (cited in Karam 2001:11). Needless to say, the hard talking of re/construction also needs to include women, but UNMIK authorities took some time to recognise their absence in the case of Kosova.

Much suffering from physical violence is experienced on a large scale at the international level and is caused by governments and those who oppose them, as well as by vigilantes, traffickers in people, and traffickers in body parts. Other types of violence-such as increased levels of domestic violence and civil conflict — have been viewed by some analysts as 'sideeffects'. A common response to violence and to the suffering it produces is to downgrade and deny it. This has been particularly apparent in the context of male violence against women in all of its forms - the most common aspects being violence in the home and rape in times of war and domestic peace. Rape and abuse of 'enemy' women in war seem to have a history as long as war itself. In the particular case of Kosova, thousands of women and girls were assaulted because systematic rape was seen as a central part of the war strategy. ${ }^{9}$ The urgent need for the comprehensive support of local women's groups willing to work on trauma counselling has been apparent since July 1999. However, such groups were initially frustrated in their efforts to carry out their work in their own ways to develop their society.

When the bombing ended and re/construction began in Kosova, there were 100,000 'internationals' in place, including 60,000 aid workers and 40,000 military personnel. Some attention was paid to the (ab)use of women's bodies by internationals and to the collusion between local and international 'entrepreneurs' for profit. That the UN Police managed to rescue even 50 women in the year following the war was possible basically because local women working on these issues had campaigned and raised their concerns at many different forums. Rather than a route for traffickers, Kosova became a destination. Cynthia Enloe (1993) assessed the symbiotic relationship between military bases and prostitution, with soldiers developing expectations of local conditions, including the availability of particular women for their 'use'. With the basis of the legislative and judicial processes undermined and without restrictions on entry or exit, Kosova quickly became recognised as a new market for trade in women's bodies. 


\section{Chris Corrin}

When war crimes have taken place, co-existence among sufferers from all sides requires thinking through ideas about 'peace with justice'. The scope of criminal responsibility needs to be widened to include leaders and commanders who lend their influence to encourage crimes against women. Such case law becomes all the more important in light of the fact that current paramilitary and militia command structures are not easily defined and are often organised covertly. During post-conflict reconstruction, general discussions about enforcing 'co-existence', with pressure often coming from international military officials, often serve to exacerbate existing tensions. The lack of a fully functioning legal system has gender implications, as judges have extensive powers of decision making, often much to the disadvantage of women. In Kosova, for example, with poorly functioning courts, women seldom receive a favourable decision in custody cases. Similarly, women's right to property is not generally recognised and, in cases of violence against women or children (including incest), despite the presentation of photos and witness statements, the courts tend to free the husband and/or father on the grounds of 'lack of evidence'. Local women's groups have worked very hard to change these circumstances and to educate women and girls about their rights.

Although women frequently constitute the majority of targeted civilian war casualties, they are not solely war victims, as their active contributions and commitment to peace and re/ construction processes testify. Given that many military conflicts are continuations of previous wars, the roots of these conflicts require analysis, and civic organisations, especially feminist groups, need to be involved in such inquiries. International community perspectives tend to view wars as inevitable, with military alliances, such as NATO, building their strategies on deterrence. Yet the shifting political administration of UNMIK means that, given the necessary opportunities and information, women's groups do have the possibility of exerting some influence on the processes of social, political, and economic reconstruction. Many women's organisations are working towards changing the way people think by their own example in constructing local, national, and international coalitions. Through their work, several groups in Kosova exemplify the transformation of the grassroots nature of women's experience of war into coalition work on reconciliation and co-existence in many different ways (Corrin 2001). More than 50 indigenous Kosovar NGOs have been at work in civic initiatives since 1999, and at least 15 are currently working to support women's needs. Several of these organisations were active before 1998, and below I give examples of good practice from several groups belonging to the Kosova Women's Network (KWN).

The KWN was founded in 1998 by Motrat Qiriazi (Sisters Qiriazi or MQ) in alliance with Lejenda, Aureola, and Elena in order to coordinate their work (see Corrin 2000 for further details on these groups). MQ has been working since 1989 to support rural women and girls, enabling them to take control of their lives and make positive changes for themselves and their communities. This group is a founding member of a network that has formed the core of much coordinated local work with Kosovar women, and its activists work alongside international feminist colleagues and sustain a dialogue with UNMIK politicians. Education for girls and women has been a key focus of MQ and within the KWN. This work is now increasingly recognised within international organisations such as the KWI as vital for taking forward women's inclusion at all levels of Kosovar society. Since November 2001, the KWN Voices newsletter and website have testified to the enormous energies women show in their community activism. With profiles of women's groups, popular chart songs against violence and harassment, and articles about the national players' travelling performances, the Network addresses all sorts of issues ranging from war rape to street harassment. Supported by the Open Society Institute and others, this initiative has a multi-dimensional character and has achieved an enormous impact throughout society (for more information, see www.womensnetwork.org). 
As can been seen from the UN Secretary-General's report, all of these areas of work are of prime importance for a society emerging from war into a post-conflict situation. With rapid and ongoing change taking place throughout a formerly tight-knit society such as that of Kosovar Albanians, women will be able to overcome some of the traumas their society has experienced only if they have access to services and educational opportunities provided locally and within a supportive framework. Working across different ethnicities is something that the KWN has been encouraging for some years in the communities it works in; having gained local trust and support before the war, its work since then has proved invaluable. In the violence of the immediate post-war phase, MQ was working in Mitrovica and continuing its activities with Serb and Roma women. Enabling the continuation of such work is something to which all 'peacekeepers' could usefully aspire. As victims of war rape and violence, many women remain in need of support, and the lack of a rule of law can easily encourage the rule of the physically powerful. Sustained, direct support for long-standing local women's groups that can network widely would alleviate some of the problems concerning disclosure of the previously undisclosed 'hidden violence'. Local groups are also aware that they need structures in place to sustain their work after the international presence is withdrawn. Several international feminist organisations have generated bilateral links in support of local women's groupsamong others Kvinna till Kvinna, Medica Mondiale, and the 'STAR' Network (although according to an October 2002 report in KWN News, donors have discontinued support for the latter's local groups' network).

One of the reasons why women's work in the KWN has added importance is that the Network has a feminist ethos in its focus on education and consciousness-raising activities at the local, national, and international level (in its attendance of international human rights conferences and seminars, for instance). Despite some very poor experience with several aspects of the international administration, reported in the GA, Kosovar activists are still able and willing to recognise when useful links need support (such as the KWI work with the emerging Women's Councils). Local women activists continue to build bridges between the UNMIK administration and local organisations. The 25 November 2002 news on the UNMIK website, for example, talked about KWN activism on the International Day Against Violence Against Women (see www.UNMIK.org for more details). There has also been much support among feminist organisations across the former Yugoslav republics. Work such as that of the Centre for Women War Victims in Zagreb (which has extended its work with refugees into Albania) and the Autonomous Women's Centre in Belgrade (Mladjenovic 2001:172-188) show that creative, caring collaboration continues across the region. Throughout the region, feminist solidarity work and friendship networks are strong and persist across the many differences, either real or imposed.

The work of the KWN in providing a powerful momentum to community consolidation has become increasingly recognised internationally. Certainly the UN Secretary-General's remarks at the Beijing +5 Conference in 2000 indicate that:

Five years ago, you went to Beijing with a simple statement: 'We are not guests on this planet. We belong here'. Five years on, I would venture that we all know this is an understatement ... not only do women belong on this planet ... the future of this planet depends on women. (Rehn and Sirleaf 2002:86)

The report by UNIFEM (Rehn and Sirleaf 2002) tackles many of the issues facing women in war and negotiated peace, highlighting the gaps in policy and in liaison procedures on overcoming the underlying reasons for women's oppression. While increasingly meetings of the Organisation for Security and Co-operation in Europe (OSCE) consider issues of human trafficking, they do not explicitly tackle trafficking as a gendered phenomenon. ${ }^{10}$ Trafficking 
in human beings explicitly targets women in specific ways, and international organisations need to acknowledge this in both their information services and their policy negotiations. There are slightly greater grounds for optimism in work from the Informal Group on Gender Equality and Anti-trafficking in Human Beings in terms of its focus on gender analysis. ${ }^{11}$ That these issues are on public political agendas that include input from experienced women gives reason for some hope. However, there is room to work toward the inclusion of a specifically feminist focus to inform gender analysis. Without a feminist focus, gender analysis can be misunderstood as 'just add women and stir' (Moser 1993). Indeed, many senior administrators with whom I spoke in March 1999 believed that 'gender' was a particular type of work that specialists can/should do without 'impinging' upon others. Ideas and comprehension about mainstreaming policies for gender equity were not widely apparent. Initiating the Gender Taskforce as a multi-agency group or forum to bring gender issues to the forefront of public dialogue and debate, UNIFEM took a much more inclusive approach to local consolidation work. This Taskforce also worked to convene key agencies on issues of importance to women. UNIFEM carried out its initial mainstreaming mandate through various forums (which successfully brought together UNMIK pillars and heads of agencies) as well as through its programmes (see Surtees 2000; Wareham 2000).

\section{Evaluation of the $\mathrm{KWI}$}

Developed during the emergency phase to focus on the reintegration of women into the reconstruction process, the KWI was funded through the US Department of State's Bureau for Population, Refugees and Migration. A budget of US\$10 million was provided for humanitarian and emergency assistance, to be managed by UNHCR, with the intention that it be spent very quickly. ${ }^{12}$ From the outset, this much-publicised initiative created tensions within local communities. Although the fund was 'for women', it was actually aimed at poor families. Undoubtedly, since women form a large part of such families, especially as war widows and heads of household, this kind of assistance does support women. However, other civic groups tended to view 'women's groups' as having privileged access to funding. This was quite clearly not the case. Funds were channelled through international 'buffer' organisations, which itself often created difficulties of access for local women, who felt that many of the projects could have been more suitably managed locally. Four international umbrella agencies (Oxfam, Maltheser Hilfdienst, the Danish Refugee Council, and the International Rescue Committee) coordinated local women's organisations to develop budget proposals. Some of these local groups came into existence simply in order to gain access to funds and some deemed it unlikely that their organisation would survive the termination of grants. That the work of the KWI was given to an already busy UNHCR officer as just a part of her remit, and was inadequately staffed or resourced, says much about the importance attached to managing this initiative. It is known that 'women' cannot be conceived as a homogeneous group, and that their identities are neither given nor unchanging. Kosovar women may be rural workers, urban professionals, older wives, young widows, translators, politicians, and so on. As Karam (2001:14) points out: 'women's interests need to be prioritized, not because they are genderspecific, but because they are the basis of the articulation of the needs of any society' (emphasis in the original). Some recognition of this need to prioritise, coupled with a fully supportive framework, would have made it possible to use the US\$10 million to create and develop a truly enabling set of programmes and policy initiatives for Kosovar women.

The independent evaluation of the KWI was finalised in October 2002 (Baker and Haug 2002). Through focus groups, interviews, and document reviews during September/October 2001, the evaluation considered the appropriateness, cost effectiveness, impact, and 
sustainability of KWI-funded activities. Comparison with similar processes in Bosnia, conducted through the Bosnia Women's Initiative (BWI), was a key focus used to assess management, coordination, and the impact of donor requirements. This focus was intended to address the broader aspects of what worked and what did not in terms of gender mainstreaming. However, whether or not conditions in Kosova at the end of conflict were similar to those in Bosnia is not considered overtly. It is true that many organisations present in Kosova were drawing on experiences from Bosnia, but it was mainly the OSCE that did the learning in Bosnia, whereas the UN had to start from scratch in post-war Kosova. The entire Kosova administration was initially run by internationals (something that occurred haphazardly in Bosnia as the UN stepped in only when all else was blocked). The fact that UNHCR had found it difficult to work with small women's groups in Bosnia did not necessarily indicate that working with women's networks in Kosova would pose similar difficulties. Having worked together for some years before the war, as part of the alternative civil society in Kosova, several of these women's groups had wide outreach and community trust and would have been capable of implementing projects. The representation made directly to UN senators by Kosovar women activists also challenges any idea that women could not manage funds.

Noting the range of project documents relating to the KWI, and the range of goals and objectives, over the 1999-2000 period, the evaluation took two goals from a 2001 UNHCR document in order to assess the KWI:

to help mobilise women throughout Kosovo, with a specific focus on returnee, displaced and war affected women; to assist them and their families in rebuilding their lives and livelihood; and to empower women to become agents of change and solidarity through raising awareness, fostering the development of women's networks and enhancing the principles of gender equity at all levels of government and civil society. (Baker and Haug 2002:iv)

Had these principles been the main, clear thrust of the KWI's work from mid-1999_ and had they been supported by strategic thinking, using gender analysis for mainstreaming throughout UNHCR institutions - it would have been possible to develop a broader, sustained framework of support for generating assistance with a gender balance. It is an insight into the crisis nature of KWI funding that such a profusion of project documents exists. When I visited the KWI staff in March 2000 they were working on six strategic areas for needs assessment: immediate survival needs; psychosocial and community support; special healthcare services; empowerment; livelihood; and legal rights and legal protection. Attention in all of these areas could have benefited local women greatly if a focused gender analysis had been employed to generate a gender-sensitive framework for decisions concerning proposals and support for continuing work. That the KWI would provide support to a war-torn country in the midst of the crisis it faced in the return to peace is not in doubt, yet the self-starting nature of Kosovar society (through their alternative arrangements since 1989) meant that there was already much to build on in terms of community collaboration.

The failure to include local, experienced, and motivated women community leaders in the implementation of the KWI's work was a missed opportunity. This is so not just for management and local ownership of the aims and goals, but for the viability and sustainability of the ethos of developing peace and re/construction. A management and supervision committee that included local women could have helped the early implementation stages of KWI funds during 1999-2000. Local women had proved themselves capable in many arenas in the years following 1989, then later during the war with their work in Kosovar communities in refugee camps, and then again from 1999 with returnees. Lessons that had been applied from the BWI about its institutional capacity and procedures not being suited to productive 
interaction with large numbers of small women's groups meant that KWI funds went into subprojects with NGOs for various sectors (such as reproductive health and microfinance) and into small project grants that were channelled through international NGOs operating as umbrella agencies. These decisions determined much in the critical 1999-2000 phase. Without an analytical frame for gender mainstreaming, the KWI was viewed as 'just a project for women', though the broader focus was on poor families and later minority ethnic communities. Sadly, these misunderstandings concerning how the project was envisioned and implemented meant that, as stated above, considerable resentment was generated among many civic groups that 'women' were 'given' US\$10 million. Organisations and networks that had been active for some years resented having to go through international umbrella groups, the staff of which were sometimes very new and inexperienced-not only in Kosovar affairs but also in international work.

Assuming the lead role as head of the Humanitarian Pillar of UNMIK, UNHCR devoted much of its capacity at the beginning to rebuild housing and infrastructure against the oncoming winter of 1999. The KWI was not prioritised at this early phase:

Implementation in this already highly complex politicised setting was undermined by a combination of conflicting priorities, low capacity, high staff turnover, lack of a detailed needs assessment, diverse goals and objectives, [and] donor pressure to disburse funds rapidly and provide special reports. (Baker and Haug 2002:iv)

There is much to be considered in the above statement, not least that the staff attempting to implement KWI initiatives were not given priority in terms of support or 'space' to present ideas and infuse some policy priorities into UNHCR and UNMIK institutions about good practice with regard to gender mainstreaming. Gender mainstreaming need not take up great resources but begins with using a gender lens and being open-minded enough to consider assessments of strategic and long-term value. UNHCR staff were not able to take on these gender mainstreaming priorities in highly charged contexts. When a senior OSCE official attempted to do so by networking with local women, she was replaced. This was not a positive image for those who remained. However, the work of UNIFEM staff did generate some successful contributions through the Gender Taskforce. The lack of apparent KWI input into such processes was a loss for all in terms of consolidating work in this area with a view to future development. It is difficult to find the root cause of the lack of cohesion between units working on gender, but there seemed to be a reluctance to collaborate, as if such work would involve competing projects in a way that would not happen under the UNMIK umbrella.

In the evaluation, the umbrella agency funding staff placed a low priority on 'specialised key technical support, sustainability, strengthening of networks and monitoring of reintegration and empowerment indicators' (Baker and Haug 2002:v), despite their status as overarching goals. This was an area of much frustration for local women's groups, which spent considerable time briefing international staff only to feel marginalised when decisions were made about how to give ongoing support; or whether, why, and under what conditions new women's groups should be started. It was in this climate that local women made interventions to US politicians, and this in turn raised questions both ways-for local groups and for international staff in Kosova. Gender funding became something of a 'hot potato' so that there were mixed reactions to the findings of the GA when it was published in May 2000. At the first all-Kosova women's conference in Priština in July 2000, local women were very appreciative, particularly of the GA's broad overview of reconstruction programmes and specific information on UNMIK procedures. It was also vital for the GA to be translated into Albanian and Serbian in order for the document to be as widely available and useful as possible to women's groups and other civic organisations. 
International reception of the GA was cautious, and even defensive in some quarters, as it was viewed as too critical of UNMIK efforts and KWI activities. At the June 2002 Fourth World Conference on Women (Beijing +5) held in New York, presentations of the GA met with a good reception among the NGO Forum groups, though with slightly less appreciation at the international formal proceedings. For women's groups in Kosova to have so much highlevel information about how UNMIK was being administered and how women's issues were being incorporated (or not) into larger agendas was crucial in giving them the power of knowledge. Information such as who the local and international co-heads of the Education Department are and how to contact them is vital for groups that are trying to push forward agendas on the education of girls. Working so hard at the grassroots rural level without such information is disempowering, so the GA worked on many levels to disseminate important, detailed information to local groups and to analyse the various reasons why members of the international mission seemed unable to prevent gender mainstreaming issues from falling through loopholes.

Much seemed to hinge on the importance given to gender equity issues when there were crises concerning demilitarisation and refugee resettlement. Women were affected by such crises in differentiated ways and gender equity was, of course, important. Here my interview with a senior UN official was indicative not just of defensiveness in Kosova regarding gender politics at that time, but also of a lack of understanding about the positive aspects that mainstreaming can bring to enhance programmes and processes. ${ }^{13}$ What transpired was a fundamental lack of comprehension about the intellectual requirements of 'thinking through gender' at budget levels, in terms of both personal security and violence issues. This is clearly not a major resource issue but is something that closed, hierarchical, institutional cultures find great difficulty incorporating into their agendas. There is certainly much room for opening up discussion on these issues given the wider remit of 'peacekeeping'. The UN Secretary-General's report also sets policy agendas that are inclusive and expansive in their thinking on mainstreaming issues, and that do not focus just on numbers but also incorporate other ways of thinking and being. This is where the real change lies.

During 2000, there was some strengthening of staffing and technical support for the KWI within UNHCR headquarters, to help improve implementation. However, UNHCR's overall focus by then was on minority ethnic communities, and the KWI followed its lead. Local women's groups had been active in this area for quite some time (see, for instance, the chronology of women's groups on www.womensnetwork.org). It has also been possible to see positive change since February 2001 when the KWI established six multi-ethnic regional Women's Councils to assume responsibility for review and appraisal of KWI grant-funded projects. The KWN newsletter gives full details of this initiative, regarding it as very positive in terms of Kosovar women's inclusion. This boost in female empowerment, achieved through their active inclusion and respect for their knowledge, could have been undertaken earlier, yet still augurs well in terms of future collaboration on similar agendas.

\section{$K W I$ sectoral and project funds}

The figures below show that by 2000 more than US\$8 million had been allocated by the KWI to sectoral support and small projects via the four main international umbrella NGOs. As Figure 1 shows, the bulk of this money (US\$7.2 million) was allocated to the sectors of reproductive health, psychosocial well-being, and microcredit, with project grants through the umbrella agencies amounting to approximately one third of the total. These umbrella agencies had a mixed record, with unsatisfactory performance 


\section{Chris Corrin}

... linked mainly to both lack of technical capacity and inconsistent management . . The choice of some partners as Umbrella Agencies who, like UNHCR, specialise in provision of relief and rehabilitation assistance may be disadvantageous in the medium to long term ... many of these agencies subsequently have difficulty in accessing development funds as UNHCR begins to phase out. (Baker and Haug 2002:45)

Of these project grants, almost half were for vocational training, with sewing, knitting, and handcrafts making up 50 per cent of the total. Performance on KWI grant-funded incomegeneration projects was disappointing: 'less than $30 \%$ showing indications of being viable ... $80 \%$ of sewing and handicraft projects funded during 1999-2000 were still operating in 2001 by virtue of a second grant from KWI' (Baker and Haug 2002:vii). This is a familiar story in small income-generation projects of this kind, though other possibilities for grants for alternative activities such as Internet projects seem not to have been fully explored. Certainly, income generation was often highlighted to me in March 2000 in discussions on the inclusion of women in the new institutional arrangements. This was particularly significant for women

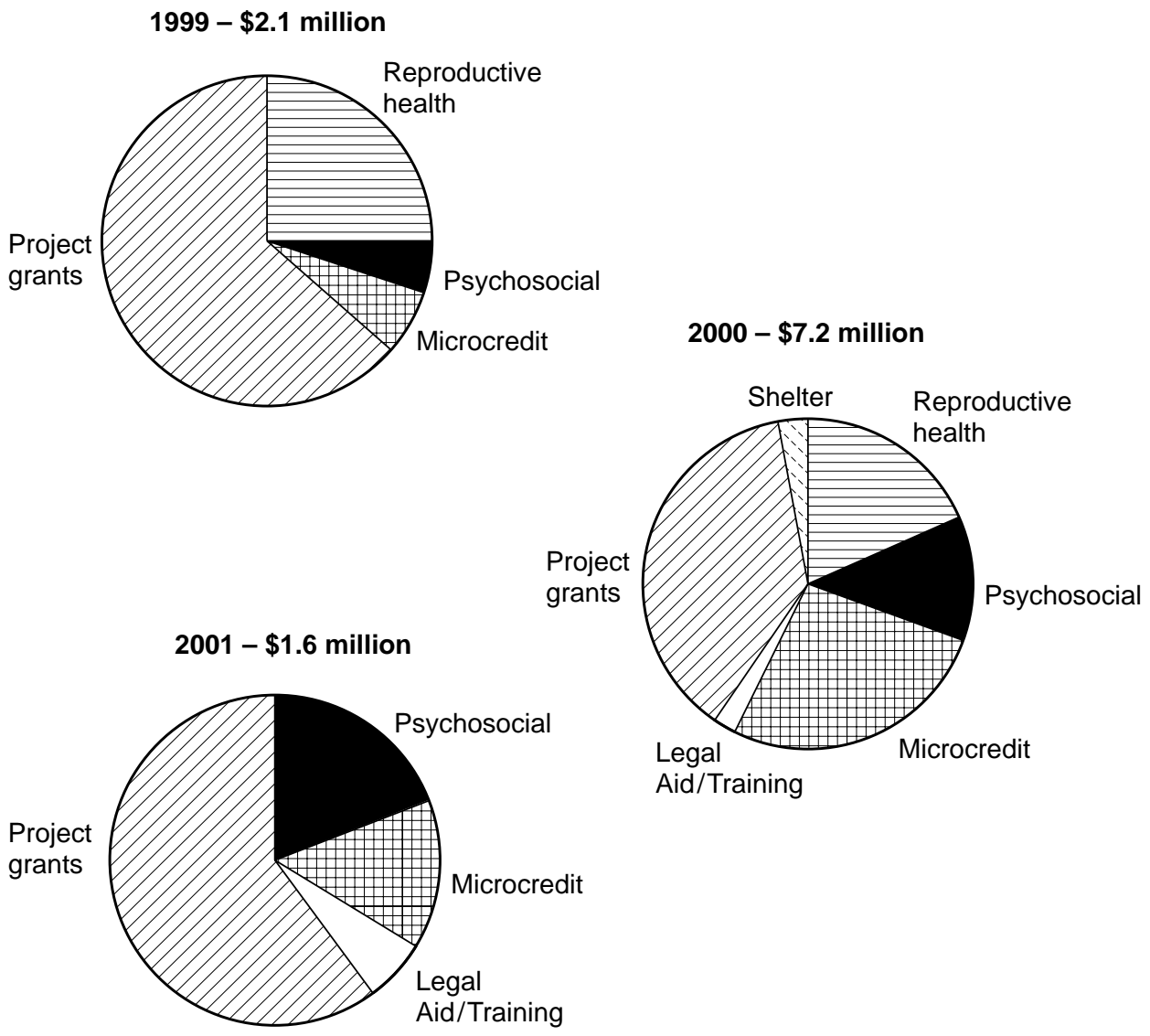

1999 and 2000 are reported expenditures. 2001 is budgeted amount. 'Project Grants' refer to projects by individual women's groups.

Source: Baker and Haug (2002), p.19.

Figure 1: Kosovo Women's Initiative fund allocations. 
heads of household, but was also viewed as a necessity for those young women who wished to continue their education as a gateway to business life. Some of the UNIFEM Gender Taskforce work in Peja in 2000 highlighted this (detailed in the GA; see Corrin 2000). However, the KWN organised a successful conference for local women in 2001 on gaining funding for activities aimed at enabling women to achieve economic independence (see KWN News at www.womensnetwork.org).

A key focus for sectoral funds involved health workers on issues of reproductive health. Long-term impact in this field depends on other factors such as girls' and women's education. The GA and others argued for development funds to be used from the KWI to support girls' schooling to ensure that young women could take up gains made through advocacy and awareness training. Strong funding in this area from KWI activities now seems less likely to be forthcoming due to the timeframe of UNHCR's exit strategy, despite the fact that education was noted as a key concern from 2002. There is perhaps a danger that giving priority to reproductive health can in turn place the emphasis on maternity/motherhood as a 'key focus' for women, whereas children's needs are a family and community concern, not solely a woman's responsibility nor a concern to be financially supported via funding to promote gender equity. In addition, the wealth of experience gained during the ten years of providing alternative 'Mother Theresa' community care and cottage hospitals may be overlooked if primary healthcare and sex education for women and girls are not given high priority (see Corrin 2000 for more information on health service re/construction). Obviously these points link closely with gender awareness in a predominantly young population, one third of which is under 15 years of age, and where the ratio of men to women aged between 20 and 50 years is 86:100 (Baker and Haug 2002:iv). Under such circumstances, the possibilities for change are potentially enormous, not limited to attempts to reconstruct old ideas about patriarchal, hierarchical ways of working but enabling the generation of nuanced and inclusive values that aim toward equity across all areas.

In certain respects, the ways in which KWI staff work was viewed as counter-productive to progressing gender agendas. On sexual and gender-based violence (SGBV) work, for example, KWI staff monitor outputs rather than impact. In this area, outputs are much less tangible than are gauging and monitoring impact, though the latter is central. Here, the KWN shows excellent results in assessing the impact of its community-based educational programmes in rural areas, in urban awareness-raising campaigns, and of course in its popular music success and theatre performances. This work is particularly successful in making links with community awareness, education, and the reduction and prevention of violence. Recommendations from the GA, regarding a holistic appraisal (using UNIFEM's Gender Taskforce idea), were to give broader support to local and other international activities in this field. Ideas arose from local staff to have health specialists visit the centres where women were based, rather than expect the women to go to the specialist centres - a daunting prospect for women in any community. Again, education is important here with a key strategy in 2002 for the KWI to invest in girls' education. Rural groups such as MQ have been implementing educational projects for many years and the KWI could have built on their knowledge and set funds aside in 2000 for educational trusts.

\section{Political dialogue}

The gendering of democratic processes in Kosova provides a good example of women's varying political involvement in re/construction and democracy building. Analysing the greater inclusion of women in peace and democracy building involves consideration of 'developing peace' (Corrin 2002). Analysts have long been aware that ideas of 'development' cannot be 
reduced to economic growth, or even to structural economic change. Instead, 'development' typically represents a vision of societal progress, a 'better' life, which includes various components such as comfort, peace, environmental balance, and more. In this context, 'developing peace' is made up of various threads that can make such things come into being, with the absence of war being just one component. For women's lives, issues of violence are often central, yet the suffering from violence is often neglected, particularly in matters of personal security. Our societies remain largely ruled according to economic figures about gross national product in which women's unpaid work (including cleaning homes, caring for children, cooking, and farming) is not counted. Monetary activity is an unreliable measure of welfare, while the suffering from violence cannot be analysed in a cost-benefit analysis, because the costs are experienced by specific people (war widows, for example) who are very different from those who benefit. The human development concept is a better indicator of the fate of women, since it includes several dimensions targeted at capturing the status of women in a given society - empowerment through expansion of capabilities and participation; equity in distribution of basic capabilities; opportunities for everybody to have at least a certain minimum; sustainability of people's opportunities to freely exercise their basic capabilities; community membership, belonging; and security, notably in their daily lives (for further discussion on this topic, see Journal of Human Development (2000) 1(1)) All of these aspects are significant in analysing women's participation in developing peace in Kosova.

Kosovar society is often described as never having experienced democracy, yet in the parallel system from 1989 there were democratic developments at the community level that mirrored 'national' governance. Much was learnt in this decade and expectations for a democratic future were high. After getting off to a very poor start in many ways, not least by not including any women in the top decision-making bodies, lessons were at last being acted upon. The 30 per cent quota for women in elections run by the OSCE is one response to the realisation that all citizens suffer through the lack of women's input. After violent conflict, many people want to move on, not just stay in the same situation. However, feminist studies again show that, in electoral terms, 'giving up' power to women is not a linear or straightforward process (Corrin 2002).

With no elected government, state building and electoral grounds remain strongly contested areas among groups in Kosova that compete from positions of varying strength in a shifting legal environment. At such times, relations of inequality between men and women can impede women's abilities to gain a political voice. Upset by violent change, during periods of flight, exile, displacement, and return, traditional aspects of gender balance lead many women heads of household to differing expectations. In analysing these changes, key areas that need to be addressed include political culture, movement 'from below' in terms of women's participation, and the significance of gender balance in politics. The incorporation of motivated women, across the spectrum of political affiliations and styles of participation, creates progressive political changes in areas in which women are under-represented. The involvement of Kosovar women in governmental and community-level politics identifies their deepening involvement across these arenas. Their work in coalitions that combine local, national, and international elements is also making a positive contribution. ${ }^{14}$

One of the most concerted attempts to bring together local women involved in work across wide sections of Kosovar society, and particularly among united Albanian and Serb women in Kosova, took place in meetings convened under the auspices of 'Women Waging Peace' held in Priština in September 2000. ${ }^{15}$ These meetings were extremely well organised by Swannee Hunt (former US Ambassador to Austria) and Vjosa Dobruna (Kosovar co-head of Department for Democratic Governance and Civil Society Support). Local women worked together in mixed groups to outline a strategic plan to work for the peaceful improvement of everyday life 
in Kosova. The following day, their plan was presented to the international gathering with senior UNMIK and OSCE officials, women politicians, and community activists from Bosnia and Herzegovina, Croatia, Slovenia, Northern Ireland, and elsewhere. Five crucial areas identified in the strategic plan were: economic development and job security; rule of law and judicial system reform; safety and security; social welfare, including health, education pensions, and orphans; and women in the political system. Concrete steps to meet targets were outlined, along with discussion of ways to take plans forward.

Beyond the group discussion were plenary sessions attended by 'top brass', including the head of the OSCE, the Security Council, and other senior UNMIK officials. These senior personnel recognised in the course of the fiery debates and forthright statements that this was not a 'PR' exercise nor a 'women's issues' meeting, but rather a gathering concerned with major socio-political problems facing Kosovar society, and with outlining ways to tackle even the most intractable issues of sustainable security (personal and societal). The head of UNMIK security offered to meet with the group working on safety and security at the end of the month, and these meetings continued throughout 2001. The wealth of diverse experience and personal courage shown by members of these meetings was awe-inspiring. Challenging from a position of knowledge is something in which some local women in Kosova are well versed in. Slowly, their voices are being heard and their suggestions acted upon.

The October 2000 municipal elections were a first step in realising UNMIK's agreement on power sharing in Kosova, leading to 'the progressive dissolution of the parallel structures'. These elections marked a watershed in Kosova's political transition, conferring international legitimacy on the local administrations. However, as can be seen in detail elsewhere (Corrin 2002), while women did gain representation, only 8 per cent of them (76 in total) were elected. The significance of this peaceful transfer of power in municipalities was significant not only for the process but as a precedent for future electoral developments. In the 'all Kosova' (not 'national') parliamentary elections in November 2001, the proportion of women elected was much higher. Overall, 34 women won seats in the three parties that gained the largest shares of the votes. Of the 47 Democratic League of Kosova (LDK) seats, 15 went to women; in the Party of Democratic Kosova (PDK), 8 of the 26 seats went to women, including Flora Brovina, dubbed Kosova's First Lady; ${ }^{16}$ and among the 26 Coalition Return (KP) seats were seven women. In the November 2002 municipal elections, women candidates saw an upturn, making up 28.5 per cent of the new municipal assemblies, 262 having been elected. Nearly all of Kosova's smaller communities received representation in the municipal assemblies for the areas where they live. Voter turnout, however, was down, from a high 79 per cent in 2000 to a more modest 54 per cent in 2002. There is some media speculation now that even the anomalous position of Kosova with regard to Serbia may be changing, with international discussions being proposed that offer the Serbian administration the possibility of EU membership in exchange for letting Kosova 'go' (for a full report on simulated negotiation, see www.usip.org). For Kosova and Serbia to reach an agreement on the independent status of Kosova would be a significant step forward in consolidating the political framework.

\section{Conclusions}

A more open, inclusive process in the implementation of international humanitarian programmes could have avoided frustrations experienced by local NGOs, some of whom have worked with Kosovar women in their communities for many years. The tendency to establish new groups to offer rural communities short-term 'choices' was often made without taking into account what already existed or examining other options. Piecemeal, short-term projects cannot substitute for longer-term planning. Local women are aware of the importance of 
creating sustainable forms of support before the internationals depart - a reflection of their anxiety that no long-term social and attitudinal changes will be made otherwise. Legislative change is only part of a process in dealing with, for example, issues of violence against women. Changes in attitudes, and recognition of the gendered nature of violence in war and domestic peace, are essential for the implementation of gender-sensitive laws and policies. Some of the partial failures of the international effort are related to the lack of a gender perspective while others are more common to the humanitarian arena. It is essential that international organisations learn from previous post-conflict situations, especially from others from nearby regions such as, in this case, Bosnia. This means examining what is comparable, however, and not assuming that Bosnian and Kosovar peacekeeping interventions and societies are identical and that 'blueprints' can be followed.

Too often women's needs and potential contributions are marginalised or minimised, not regarded as a vital ingredient in all reconstruction processes. This can perpetuate a belief that women in Kosova are not 'culturally attuned' to becoming partners in community or regional politics, but remain victims and, therefore, recipients of aid and assistance rather than active partners in reconstruction efforts. There are always specific aspects to take into account within a global human rights framework. Some of the OSCE work in schools in relation to human rights campaigns is contributing to widening knowledge. ${ }^{17}$ With regard to girls' education, post-war trauma, poverty, and insecurity will prevent some girls from completing eighth-grade schooling. Given the high percentage of under-15s among Kosovar citizens, this is an area in urgent need of international support. With EU funding, groups such as the Amsterdam-based Academic Training Association are undertaking higher education reforms at both undergraduate and postgraduate levels. The Canadian International Development Association (CIDA) has put many millions into teacher-training programmes and support. Education within the international media is also important, to portray positive images of Kosovar women-as capable, courageous, and confident-in order to strengthen rather than undermine their activities and aims. Here, KWN performances support stronger perceptions of women that are in turn reported through the various media. Little attention had been paid to the tendency of the international media, from 1991, to portray 'Balkan women' and/or Muslim women in negative terms (see Corrin 1996). Attitudes concerning 'traditional' societies could usefully be discussed, certainly within the context of how war rips apart closely knit communities with loss of life, trauma, and material devastation. New ways of bonding and supporting 'in community' develop slowly in such awful circumstances, yet they do develop, and within this women's strengths can become recognised afresh.

An assessment of how women's groups in Kosova can enter the political dialogue from a more empowered position links with activities in other post-conflict situations. Women active in this area are keen to share findings and discuss comparisons and differences in ways of working towards similar goals across different regions. Enabling the inclusion of local women requires international support at various levels, rather than official decisions being made about what women need (or do not need) without any reference to women themselves. An example of this was apparent in the case of tractors for families in Kosova. ${ }^{18}$ Many women were not considered suitable for training in how to drive tractors and operate heavy machinery within an agenda where gender and ethnic bias coalesced to prevent women from making their own choices. Ideas concerning 'Muslim women' and 'traditional cultures' have often been put forward as concrete reasons not to empower rural women in Kosova and elsewhere (see, for example, Walsh 2000). Rather than considering women generally as targets for short-term lowlevel funding, or primarily humanitarian crisis funds, it is also necessary to train them in many other areas, including management. Translating theory into practice proved both complex and problematic in certain sections of the international mission in Kosova. Clearly, processes of 
gender mainstreaming must be both two-way (i.e. happening within international and local structures) and transparent. Key aspects include the need for sex- and age-disaggregated statistics so that ratios of women/girls and men/boys can be studied in a range of settings, engendering policy-making implications for different groups, and gender mainstreaming throughout administrative and political decision making. The lack of gender balance and gender analytical skills within the international administration had clear 'knock-on' effects in decision making in post-conflict Kosova.

The pace of change is important, but the need to include, and show respect for, local knowledge and the involvement of Kosovar personnel cannot be overemphasised. Many local women spent much time and energy giving information and advice to the small team of gender specialists in UNMIK, only to be frustrated by the lack of coordination and feedback, and the continued failure to draw upon their expertise in the implementation phase. The current KWI evaluation is a good start in learning from this process in the case of Kosova, yet the excellent report on successes in gender inclusion from the UNTAG mission in Namibia took ten years to gain serious consideration (Olsson 2001:97-110). Forming a base for mainstreaming the training of gender analysis would help ensure equitable progression for women and men in any reconstruction and reintegration processes. Working with gender issues considers the needs, involvement, and decision making of women as well as men in a community, in order to understand how unequal power relations are shaped by and built into social institutions of family, legal structures, religious systems, and beliefs. The reaction from some senior UN officials exemplifies a mind-set that persistently regards issues concerning women and girls as secondary, and views gender equality policies as being in competition with other 'important' (often 'national') issues. Yet gender analysis is an integral part of the solutions, a lens through which to view the development of just and equitable policies, the implementation of which does not depend on vast resources. Basically, all the arguments over funding and projects come down to an issue of respect. Local women who resisted external oppression are not prepared to be patronised by US officials in Kosova nor treated as aid recipients or victims. Engendering an inclusive dialogue on this will certainly help to develop strategies for supporting women in emergencies as being central to reconstruction, with gender a key factor in mainstreaming equity issues, instead of putting 'aid' into scattered women's projects. The failure to engage in partnership with local women's groups emerging from war has proved a major loss for achieving such goals in Kosova. In 2002 the KWI is now working more closely with the $\mathrm{KWN}$ in various reconciliation projects.

At an international level, there are grounds for optimism with regard to the movements towards the full inclusion of women's interests and voices in future peace negotiations and reconstruction processes. It is clear that during situations of crisis and reconstruction, donors and international organisations in the field are beginning to give greater appreciation to and consideration of women's initiatives within their remits. In recommending the report on Women, Peace and Security to the UN Security Council, Kofi Annan proposed that: 'Just as your work can promote gender equality, so can gender equality make your work more likely to succeed' (UN press release 4 November 2002). With their online newsletter the KWN show the enormous creative energies going into their various projects. Their popular song Fundi im I shkurte (My Short Skirt) was in the charts. This came out of stories based on the Vagina Monologues (international work to eliminate violence against women around V-Day by playwright and activist Eve Ensler. ${ }^{19}$ Requests for their performances of women telling their stories have been made from Switzerland and other countries with sizeable Albanian populations. In these and other ways, they are proving the adage that women's empowerment is community empowerment! 


\section{Acknowledgements}

I wish to thank those who patiently took time in Kosova to discuss their situation and to answer many queries. My gratitude also goes to Mary Diaz (WCRWC) and Ariane Brunet (UAF) for facilitating the initial visit to Kosova for collaboration on the Gender Audit; as well as to various readers and all the feminist friends throughout Central and SE Europe without whom this work could not have been done.

\section{Notes}

1 I use the term Kosova because this is term that the majority Kosovar Albanian community uses. Using 'Kosova' (rather than 'Kosovo') during the hostilities with the former Republic of Yugoslavia, particularly since 1998, signalled a move towards independence for many groups and individuals.

2 The Gender Audit was commissioned by the Women's Commission for Refugee Women and Children (which, since 1989, has sought to improve the lives of refugee women and children through vigorous programmes of public education and advocacy, and by acting as a technical resource) and the Urgent Action Fund (created in October 1997 to promote the human rights of women within the context of strategies outlined in the Beijing Platform for Action).

3 See websites in the references for the full text of both UN reports and the KWI review.

4 Judith Hicks Stiehm emphasises how these new activities directly affect women and women's opportunities for participation in international operations, with opportunities for women to direct these new aspects of peacekeeping being more in accordance with gender mainstreaming policies. The author argues that the implementation and institutionalisation of these new policies requires commitment, resources, and sound strategies to overcome institutional inertia and, sometimes, resistance. (See Olsson and Tryggestad 2001:39-48.)

5 The term Kosovar Albanian distinguishes Albanians in Kosova from those from Albania. As explained in Note 1, Albanians generally spell this 'Kosova', although 'Kosovo' is often used within the international community and is acceptable to the Serbian régime. The issue of which of the two spellings to adopt was a highly political one in the context of resistance to Serb domination.

6 More research is needed to consider the links between the terms on which women participated in the resistance struggle and the transformation of gender politics during peacetime under the UNMIK administration.

7 As is fully discussed in feminist discourses, 'women' are not a homogeneous entity. In Kosova the struggle against Serb aggression involved Kosovar Albanian, Serb, and Roma women in differing ways. This is true of the impact of the NATO bombing and most certainly apparent in the post-war situation. While many Serb and Roma women fled Kosova in the immediate post-war period, many also stayed behind. It is those who remained who are working across major divisions (both physical and psychological) to achieve a constructive engagement for peaceful reconstruction.

8 In one village in eastern Kosova only eight men returned.

9 See Human Rights Watch (2000); 'War and rape: a digest of referenced articles' at www.flora.org/flora.mai-not/17300; Fitamant (2000); and Wareham (2000).

10 Neither the Tirana meeting of the newly formed OSCE Victims Assistance on 27 November 2002 (giving assistance to trafficked women sent back from Italy), nor the workshop in Skopje on 25 November 2002 (on human trafficking investigation) highlights gender as a key variable in the analysis of human trafficking. 
11 See summary of the 8 October 2002 meeting by H.E. Ambassador Del Marmol and Dr Gracheva, Chairpersons of the Informal Group on Gender Equality and Anti-trafficking in Human Beings, PC.Del/904/02, 5 November 2002.

12 Similar initiatives had been implemented in Bosnia (BWI US\$5 million) and in Rwanda (RWI US\$7 million). In each of these projects, it remains unclear how economic projects such as income-generating initiatives aimed at the most vulnerable groups of women redress wider inequalities in gender relations.

13 In a rather bizarre conversation, the official told me that he could not discuss gender issues as there were not enough policemen in Kosova (!). Ironically, I soon discovered (March 2000) statistics showing that 24 per cent of the Kosovar police force was women, while the UN police force had only 6 per cent women.

14 Various case studies in Moser and Clark (2001), particularly those of Simona Sharoni and Urvashi Butalia, detail the work of such coalitions towards sustainable peace. Cynthia Cockburn (1998) also analyses women's often difficult and dangerous work across differences towards ending conflict and violence. In the context of south-east Europe, the work of the Gender Taskforce of the Stability Pact under the direction of Sonja Lokar has been significant in post-war electoral political campaigns. Here regional coalitions have been formed to support women standing in various elections under the networking banner of 'Women Can Do It'.

15 This is a global initiative hosted by the Women and Public Policy Program of the Kennedy School of Government at Harvard University.

16 Flora Brovina, a doctor and women's activist, was sentenced in 1999 to 12 years' imprisonment under the Milosevic régime, and was released in 2001. She was put in the ballot by the Democratic Party of Kosovo (PDK) as a presidential candidate and her campaign caused much discussion, not least about having a 'woman President'. Her humanitarian work has won international recognition and she won the UN Millennium Peace Prize for Women. For more details, see 'Kosovo's First Lady' in the Guardian 15 November 2001.

17 A year-long human rights campaign in Kosovar schools concluded in June 2002. Every month of the year, 150 classes representing around 1800 pupils in grades 7 and 8, from all regions and communities of Kosova, prepared calendars in a human rights awareness campaign. Using interactive media to promote discussion and activities, the children reported on the texts and drawings they produced (see OSCE press release 7 June 2002).

18 All families who had owned a tractor before the war were entitled to receive one afterwards, but some UNMIK officials decided that for those women heads of household who were not themselves able to drive tractors, men could be hired to do ploughing for them. There are several misunderstandings here about what women are entitled to and about what they can do. Firstly, women heads of household were entitled to tractors regardless of what they used them for; and, secondly, many women wished to be trained to drive tractors and to operate other heavy farm machinery.

19 V-Day is a global movement to stop violence against women and girls. For more details, see www.vday.org.

\section{References}

Baker, J. M. and H. Haug (2002) Final Report: Independent Evaluation of the Kosovo Women's Initiative, Geneva: UNHCR (text available at www.unifem.undp.org). 
Butalia, U. (2001) 'Women and Communal Conflict: New Challenges for the Women's Movement in India', in C. Moser and F. Clark (eds.).

Cockburn, C. (1998) The Space Between Us: Negotiating Gender and National Identities in Conflict, London: Zed Books.

Cockburn, C. (2001) 'The gendered dynamics of armed conflict and political violence', in C. Moser and F. Clark (eds.).

Corrin, C. (1996) Women in a Violent World: Feminist Analyses and Resistance across 'Europe', Edinburgh: Edinburgh University Press.

Corrin, C. (2000) Gender Audit of Reconstruction Programmes in South Eastern Europe, New York, NY: Women's Commission for Refugee Women and Children and Urgent Action Fund (text available at www.gla.ac.uk/centres/icgws).

Corrin, C. (2001) 'Post-conflict reconstruction and gender analysis in Kosova', International Journal of Feminist Politics 3(1):78-98.

Corrin, C. (2002) 'Developing democracy in Kosova: from grassroots to government', Parliamentary Affairs (Special Issue: 'Women and Politics Revisited') 55(1):99-108.

Davies, M. (ed.) (1994) Women and Violence: Realities and Responses Worldwide, London: Zed Books.

Enloe, C. (1993) The Morning After: Sexual Politics at the End of the Cold War, Los Angeles, CA: University of California Press.

Fitamant, S. (2000) Assessment Report on Sexual Violence in Kosovo, New York, NY: UNFPA.

Hasani, E. (2000) Dissolution of Yugoslavia and the Case of Kosova: Political and Legal Aspects, Priština: Albanian Institute for International Studies.

Human Rights Watch (2000) Kosovo: Rape as a Weapon of 'Ethnic Cleansing', New York, NY: Human Rights Watch.

Jacobs, S., R. Jacobson, and J. Marchbank (eds.) (2001) States of Conflict: Gender, Violence and Resistance, London: Zed Books.

Judah, T. (2000) Kosovo: War and Revenge, New Haven, CT: Yale University Press.

Karam, A. (2001) 'Women in war and peace-building: the roads traversed, the challenges ahead', International Feminist Journal of Politics 3(1):2-25.

Maliqi, S. (1998) Kosova Separate Worlds: Reflections and Analyses 1989-1998, Priština: Dukagjini PH.

Meintjes, S., A. Pillay, and M. Turshen (eds.) (2001) The Aftermath: Women in Post-conflict Reconstruction, London: Zed Books.

Mertus, J. (1999) Kosovo: How Myths and Truths Started a War, Los Angeles, CA: University of California Press.

Mladjenovic, L. (2001) 'Caring at the same time: on feminist politics during the NATO bombing of the Federal Republic of Yugoslavia and the ethnic cleansing of Albanians in Kosovo 1999', in S. Meintjes, A. Pillay, and M. Turshen (eds.).

Moser, C. (1993) Gender Planning and Development: Theory, Practice and Training, London and New York, NY: Routledge.

Moser, C. and F. Clark (eds.) (2001) Victims, Perpetrators or Actors? Gender, Armed Conflict and Political Violence, London: Zed Books.

Olsson, L. (2001) 'Gender mainstreaming in practice: the United Nations Transitional Assistance Group in Namibia', in L. Olsson and T. L. Tryggestad (eds.).

Olsson, L. and T. L. Tryggestad (eds.) (2001) Women and International Peacekeeping, London: Frank Cass. 
Rehn, E. and E. J. Sirleaf (2002) Women, War and Peace: The Independent Experts Assessment on the Impact of Armed Conflict on Women and Women's Role in Peace-building, New York, NY: UNIFEM.

Sharoni, S. (2001) 'Rethinking women's struggles in Israel-Palestine and the North of Ireland', in C. Moser and F. Clark (eds.).

Surtees, R. (2000) Women at Work: The Economic Situation and Opportunities for Women in Kosovo, Priština: UNIFEM and DFID.

United Nations (2002) UN Security Council: Report of Secretary-General on Women, Peace and Security: S/2002/1154, 16 October 2002 (for full text, see www.un.org).

Waller, M., K. Drezov, and B. Gokay (eds.) (2001) Kosovo: The Politics of Delusion, London: Frank Cass.

Walsh, M. (2000) 'Aftermath: The Impact of Conflict on Women in Bosnia and Herzegovina', Working Paper No. 302, Center for Development of Information and Evaluation, Washington, DC: USAID (for full text, see www.dec.org/pdf\%5Fdocs/PNACJ322.pdf).

Wareham, R. (2000) No Safe Place: An Assessment on Violence against Women in Kosovo, Priština: UNIFEM and DFID.

\section{The author}

Chris Corrin is Professor of Feminist Politics and coordinator of the International Centre for Gender and Women's Studies at the University of Glasgow in Scotland. Her publications include: Superwomen and the Double Burden (Scarlet, 1992); Magyar Women (Macmillan, 1994); Desperately Seeking Sisterhood (Taylor \& Francis, 1995); Women in a Violent World (Edinburgh University Press, 1996); Feminist Perspectives on Politics (Pearson, 1999); and Gender and Identity in Central and Eastern Europe (Frank Cass, 1999); as well as a variety of articles on women's politics and development. Contact details: Politics Department, University of Glasgow, Glasgow G12 8RT, Scotland, UK. <c.corrin@socsci.gla.ac.uk>; www.gla.ac.uk/centres/icgws 